\title{
Muslim Cosmopolitanism in Rural Bangladesh: The Construction of Power Dynamics vis-à-vis Cosmopolitan Identity
}

\author{
Md. Nizam Ul Hossain
}

Nodi Islam

\begin{abstract}
The article addresses how the migrant Bangladeshi workers, in their bid to be a part of the Middle Eastern Muslim Cosmopolis, make sense of the negotiation between the concepts of nation-state and umma. The article also examines whether these migrants' endorsement of a 'foreign' Muslim culture in Bangladesh has created a community of 'other' Muslims perceived to be less Muslim because of being less exposed to the Middle East culture. In a rapidly changing context in terms of cultural identification, it is pertinent to investigate if the power, prestige, and privilege that these Bangladeshi migrants enjoy in Bangladesh rely solely on their becoming 'better' Muslims or rather chiefly stem from their monetary gain. The article explores whether a good financial status becomes the driving force in creating the Muslim 'other,' and how it has been inspiring others to migrate to the Middle East to become successful and 'Global' Muslim Citizens. The concepts of umma and cosmopolitan constitute the conceptual framework of the study. The study also presents a critique of cultural influence and identity construction based on faith. In addition, some migrants were interviewed to reflect upon their experience and the role of religious affiliation in the construction of cosmopolitan Muslim identity. Both collective conscience and the sense of religious affinity are addressed.
\end{abstract}

\section{Keywords}

Muslim Cosmopolitanism, Cosmopolitan Identity, Migration, Hierarchy, Power Dynamic. 


\title{
Muslim Cosmopolitanism in Rural Bangladesh: The Construction of Power Dynamics vis-à-vis Cosmopolitan Identity
}

\author{
Md. Nizam Ul Hossain
}

Nodi Islam

\section{Introduction}

For the past two decades, Cosmopolitanism has become the new buzzword (Leichtman et al. 1; Song et al. 346). A fair portion of its meanings can easily be traced to the Cynics or the Stoics in Greek antiquity, and other meanings to the $18^{\text {th }}$-century elaboration of the concept of Cosmopolitanism by Immanuel Kant. Famous authors such as Marx and Engels even postulated a new cosmopolitanism that is linked to the contemporary processes of globalization, deregulation of markets, post-nationalism, migration, and feminism (Petrus 801). Derived from the Greek conjunction of "world" (cosmos) and "city" (polis), cosmopolitanism describes a "citizen of the world," one who is not rootless but embedded in concentric circles of identity and "puts right before country, and universal reason before the symbols of national belonging" (Nussbaum 156). Thus, Cosmopolitanism may characterize a certain perspective on the whole world, both social and cultural conditions, a political subjectivity, an attitude, a political project, and finally, a practice or competence. In his interpretation of the concept, Appiah's intertwines two strands of his distinguished moral manifesto:

" One is the idea that we have obligations to others, obligations that stretch beyond those to whom we are related by the ties of kith and kind, or even the more formal ties of a shared citizenship. The other is that we take seriously the value not just of human life but of particular human lives, which means taking an interest in the practices and beliefs that lend them significance". (Appiah xv)

Given the considerable conceptual indeterminacy of the term (Pollock, Bhabha, 
Breckenridge and Chakrabarty 6-10), cosmopolitanism leaves ample room for scholars to attribute to its various advantages. Ulf Hannerz highlights the concept's use for anthropologists as they move back and forth between "the local" and "the global," blurring the initial, problematic contrast between the two (Hannerz 237-238). Werbner envisions a new anthropology of cosmopolitanism, grounded ethically in ideas of tolerance, inclusiveness, hospitality, personal autonomy, and emancipation (Werbner 497). This actually challenges many of the articulations of this concept in other disciplines: that is declining the outlook that cosmopolitanism is singularly an elitist concept; suggesting that cosmopolitanism's rudimentary values are not necessarily "Western"; dictating that not all of the postcolonial cosmopolitans are travelers and necessarily need not to inhabit or shift permanently beyond their nations and cultures; and emphasizing on the point that cosmopolitanism contemplates the endeavor for universal ideals and local multiculturalism within a particular field of authority.

For anthropologists, "vernacular cosmopolitanism" has been particularly popular. Homi K Bhabha in writing against the universalism of Nussbaum used the term to suggest a cosmopolitan community envisaged in "marginality" (Bhabha 198). Werbner, like some contributors to this special issue, groups vernacular cosmopolitanism with similar concepts that combine contradictory opposites and suggest multiple modalities of cosmopolitanism (Werbner 497): cosmopolitan patriotism (Appiah et al. xiv); rooted cosmopolitanism (Cohen 8); cosmopolitan ethnicity (Werbner 496); working-class cosmopolitanism (Werbner 498); and discrepant cosmopolitanism (Clifford 363). All these terms focus on the multitude of practices that comprise, and stem from, a cosmopolitan disposition, and these terms are cored in regionally diversified historicity and worldviews.

By devoting this to "Muslim cosmopolitanism," we can homogeneously center concentration on cosmopolitanism as a certain set of practices, a configuration, and a specific cultural and social condition that allows Muslims to inhabit the contemporary world. According to Joseph A. Camilleri, Muslim cosmopolitanism refers to a style of thought, a habit of seeing the world, and a way of living that is rooted in the central tenet of Islam, which is that everyone is part of a common humanity accountable to God and we are responsible to one another (Camilleri 1).

In his book Muslim Cosmopolitanism: Southeast Asian Islam In Comparative Perspective, Syed Khairudin Al-Junied argued that Muslim cosmopolitanism exhibits a high degree of receptiveness to universal values that are embedded within one's own customs and traditions (51). Internalizing Muslim cosmopolitanism enables a person to be at ease with his or her own Islamic and cultural identities, promoting these identities as a means to enrich public understanding about Islam and Muslims while maintaining and embracing an open attitude towards people of other backgrounds. Muslim cosmopolitans seek to ensure the protection of faith, life, lineage, intellect, property, and rights of all groups and individuals in society. As living embodiments of Muslim cosmopolitanism, they are committed to a set of practices and actions (Aziz 1). 
In the present world, as Appiah would consider, Muslim cosmopolitanism is articulated through its engagement with the state, business and economics, history, fashion, and imagination (Appiah xv). For the citizens of a Muslim country, Muslim cosmopolitanism is a contested category of practice, an experience, and a heuristic concept that indicates to a variety of images, a future possibility that is grounded in present-day realities. The Muslim cosmopolitans are not only limited in the concept of residing in capital cities or major financial centers but are also connected with small, remote, and marginalized villages and towns (Leichtman and Schulz 3). For that reason, Muslim cosmopolitanism at once can be both Universalist in its identifying with the global Islamic umma (community of believers) and its rootedness in particular local histories.

\section{Rural (Muslim) Cosmopolitanism}

A feature of contemporary cosmopolitanism has been the increased, extended, and intensified mobility of migrants from, to, and through the global countryside (Woods 490). In a lot of rural areas, this experience has been primarily identified in terms of reinforced out-migration, either to domestic cities or internationally, on a permanent or temporary basis, as individuals engage the global economy along with the differentiated geographies. Yet, in, substantial parts of rural Asia; especially in Bangladesh this phase has been associated with a new dynamic of immigration since the beginning of the twenty-first century. The adaptability process that controls this immigration includes, variously, return migration by former emigrants, transnational lifestyle or amenity migration, and the resettlement of asylum seekers and refugees, even so specifically the international transmission and flow of migrant labor force, which has become a major component of the neoliberal rural economy. And behind these factors there lies the issue of religion- which sometimes becomes a solid point to migrate in any particular region of the migration able world.

"Rural cosmopolitanism sounds like an oxymoron" (Johansen 1). The very coupling of the terms grates with engrained cultural sensibilities that have conventionally associated cosmopolitan traits of global engagement, cultural hybridity, and openness to difference with the city, whilst portraying rural communities as insular, parochial, monocultural, and in short, non-cosmopolitan (Johansen 2; Short 34; Woods 490). Although critical rural studies have critiqued such discourses by revealing the complex interlocal connections and cultural diversity of rural communities' even before recent patterns of migration, the fixing of cosmopolitanism to urban society has been reinforced by an emphasis in the broader literature on cosmopolitanism as an attribute of elite, transnationally mobile, relatively privileged social actors, whose life-spaces are anchored in global cities (Hannerz 240-243; Kanter 165; Sklair 2). As Gidwani and Sivaramakrishnan remark, this characterization implies that "there are distinct domains of those who are cosmopolitan and those not yet there" (Gidwani 344), and thus "wittingly or unwittingly, taints the idea of cosmopolitanism with the dangerous pieties of modernization theory - that people, places, and cultures exist at different stages of 
development, and those who are not cosmopolitan suffer from some sort of lack." (Gidwani 344)

\section{Identity}

In general, identities are both attributed by others and advocated by individuals. According to Campbell Leaper and D. Abrams, identities can be heavily influenced by social groups and historical circumstances (1). They can also be situational, flexible, and determined by individual choice. People may define their identities in many ways, such as by gender, age, and ethnic, racial, religious, or other affiliations. Many individuals have global, cosmopolitan, or multicultural belongings and identities. Some reside in more than one country or lead transnational lives going back and forth between countries (Case 86). Within Muslim communities, Muslim identity refers to obedience to common and specific ideas and faiths. A Muslim community constructs the identity of a Muslim. To be both Muslim and cosmopolitan, one has to be Muslim from somewhere inbetween. Specifically, one has to be from some space and place identified by versatile boundaries, multiple ways of both being and seeing, while also living and feeling the world at the same instance. Muslim brotherhood addresses such identitarian norms which are mandatory to be a part of the community.

Concerning this issue, religion, both as an institution and in terms of personal attitudes and involvement, probably plays a role that should not be neglected. This is partly because, generally speaking, the construction of personal identity, especially among adolescents and young adults, is to a certain extent influenced by religion (Pancer et al. 41). It is also because religion is part of a larger cultural whole concerning which people regulate their degree of belonging. Additionally, the role of religion is very important for multiple collective identities, particularly in the context of immigration: religion seems to play a role in the construction, preservation or abandoning either of local and ethnic/national identities or transnational and global ones (Burris et al. 518), and this is especially the case among immigrants. Also, Local, regional and global factors interact to give rise to Cosmopolitan thinking.

Most of the Bangladeshi migrant workers are from rural areas. Like many others, their Islamic faith and Muslim identity are based mostly on Arab Muslim norms. The Arab traditions of Islamic ritual and culture play vital roles in their life which constitute their behavior, attire, activities, and ritualistic actions. Now in the case of people of rural areas in Bangladesh, the majority has no idea of the difference between national identity and religious identity. Mostly they prefer being a "Muslim" than a "Bangladeshi". For them, being a Bangladeshi means involving many other customs from Hinduism and thus pollutes their identities. Only being a "Muslim" can make one a purer individual devoid of any national secular idea or boundary. Their conception of a nation-state is fragmented and does not involve larger engagement with local grass root moments. There is a desire to belong to a pure transnational Muslimhood. Muslim umma on the other hand prevails to be a purer space for "Muslim" Muslims. The umma is the community which follows 
the Middle Eastern norms is all the cosmos they need to live as a purer Muslim(Azra 104). This idea of Muslim umma as a purer one comes from the Islamic myths and stories involving the prophets and messiahs of Islam- all belonging to countries in the Middle East. Also, the holy place of Muslim pilgrimage is situated in Arab. These ideas make the Middle East the land of the pure and encourage the umma which is to follow Arabic norms. Further, if negotiation between umma and nation comes to concern, such Bangladeshi people will opt for the umma as their cosmopolitan identity instead of national identity because umma provides the purer identity of Muslims and only to Muslims(Appleton 178).

Vertovec and Cohen argue that travel and immigration have led to a greater acceptance of diversity, of "everyday" or "ordinary" cosmopolitanism (Cohen and Vertovec 5). Even now surely, an investigation of Muslim cosmopolitan practices and competencies needs to be a concern with the account of the discursive and political parameters which since September 11, have inflected scholarly debate on whether "Muslims" or "Islam" should be conceived and considered as part or as the Other of a new cosmopolitan set of products. In Bangladesh, immigration to foreign countries has been a major source of work and foreign currency for a long time. But after the 9/11 terrorist attack, there was a visible drop-down of allowing working visas to Muslim workers from both the Middle East and Southeast Asia region. Many of these workers were considered as an oppression of the Non-Muslim World and as Middle Eastern countries offered them jobs, they considered them to be the rescuer as also they shared the same religion.

\section{Muslim Cosmopolitanism in Bangladesh}

\section{Migrant Bangladeshi Workers}

Every year Bangladesh exports manpower in a great number to Middle Eastern countries like Saudi Arabia, Dubai, Kuwait(Kapiszewski 87). This involves a one-sided journey with no considerable mutual influence. Mostly the people from rural areas in Bangladesh go for the Middle Eastern human exchange. The rural areas where technology is not on the cutting edge or economic source is limited and the educational rate is relatively poor tend to have comparatively a high rate of sending workers to these countries. The monetary gain is the prime concern that begets power and respect for them in their motherland. These workers are hired to do odd jobs in Middle Eastern countries. Their job opportunities involve those of slaves of the rich "Sheikhs" or factory workers or mine workers or sometimes as sex slaves. Their toils pay them off with a larger amount. As a result, the status in their country enhances from low to high class in the rurality. Money buys them power, status, and a new identity. 


\section{Case Study}

\section{Method}

\section{Participants and procedure:}

The study employs a mixed-method for collecting and analyzing data. The concept of imagined 'umma' and cosmopolitanism are critically examined in relation to relevant theoretical frameworks. In addition, a qualitative method was employed. A structured interview was administered to 45 middle-aged Muslim migrant workers (minimum and maximum ages $=35,40$, and 50 years). To gather information, invitations for individual or group interviews were sent via phone call to a selected 45 Muslim immigrant workers from Kompanigonj, Noakhali; who are working/have worked/worked in Middle Eastern countries, 9 of whom were women and the rest 36 were men. 8 of them denied to be interviewed in any way, 10 of them wanted to give a non-formal personal interview and among the rest 27 of them, 6 participated in a group interview and 21 of them were interviewed personally, in both of which an open-ended question and answer format was used. Of the 27 people who have given Formal interviews, 4 of which were women and the rest 23 were men. Some of the interview sessions have been formally recorded with permission for future documentation and those who did not approve of a formal interviewing and thus the conversation with them is not retained for further analyses.

Among the migrants, $83 \%$ are mostly second-generation immigrants, while the remaining $17 \%$ of them belong to the first-generation and none of them were thirdgeneration immigrants. The participants have been living in these six Middle Eastern countries - Saudi Arabia, Qatar, Kuwait, United Arab Emirate, Oman, Bahrain where they are working as migrant workers in different governmental and non-governmental sectors. Both types of job holding migrants are officially recognized, follow similar programs, and have an equivalent number of migrants who are traveling every year to get into jobs like those. The Middle Eastern countries were selected according to their residing neighborhood to increase the likelihood of finding high rates of immigration. The study was advertised as an investigation about several dimensions regarding the values of migrating in a Muslim country and what cultural and religious significance does this brings to the migratory population in Bangladesh. The protocol was administered in person by the means of formal interviewing. The migrant workers were informed that they can choose not to participate in any conversation they might not wish to. To complete an interview, it took approximately 20 minutes. In the end, participants were thanked for their contribution and a month later were informed of the results of the study through a summary.

\section{Measures}

The interview was composed of questions regarding reasons behind migration, 
reasons to choose a Muslim country to migrate into, the working condition, experience and salary, various religious measures, and identity- and acculturation-related measures. The participants have all lived and worked in Middle Eastern Countries like Saudi Arabia, Qatar, Kuwait, United Arab Emirates, Oman, and Bahrain. The majority of them have lived in Saudi Arabia and Qatar for more than 10 years. Depending on their jobs and visa status, they are constituted into two groups -

1. Migrant workers who went to Middle Eastern Countries carrying a legal working visa and worked under reputed organizations as consultants, Doctors and Laborers. $(\mathbf{n}=\mathbf{1 8})$

They applied for immigration through the Bangladeshi governmental organizations and hold an active "Akama" which permits them to work in the country they have migrated in. This group of workers has barely faced any legal problem and has an appreciative attitude towards immigration and earning in Middle Eastern countries.

Migrant workers, who carried an illegal visa, worked anonymously and later were forced to come back to Bangladesh. $(n=9)$

This group of workers has worked mostly as day-to-day laborers under some very inhuman conditions though their earnings were 'good' according to some of them. They gained illegal visas to arrive in countries like Qatar, Saudi Arabia, and Kuwait through non-governmental Immigration agents. A lot of them had run into legal problems with local authorities and the police and had to pay fines to be freed from jail. All of the workers from this group had to return to Bangladesh permanently due to legal and working problems in their migrated countries.

It is to be mentioned that despite their legal and illegal visa issues, many of these workers have known and resided with each other for many years.

\section{Questions:}

Questions in the interviews were asked considering these below-mentioned issues
a. Intensity of religiousness
b. Reasons behind migration
c. Duration of stay in Middle Eastern Countries
d. Good and Bad Experiences
e. Doing both Legal and Illegal jobs
f. Amount of earning
g. Change in Economic and Social Status.
h. Attitude towards Nationality and Umma.

\section{Findings:}

Upon interviewing both groups of migrant workers, it becomes evident that due to their legal and illegal visa statuses and the amount of earning, their experience in and of Middle Eastern countries are constituted very differently which result in them seeing 
their own country and their Muslim identity both in and out of Bangladesh in very different ways.

a. Willingness and the reason behind for migrating to a Muslim country: When asked why they chose to go to a Middle Eastern country, the interviewees responded that some of them already had relatives or friends in those countries who helped them migrate, the income would be good and it would be easier for them to work and navigate in a Muslim country where they know the religion. While they certainly faced a different Islamic culture there than the Bangladeshi one, they adapted to the situation as they learned from the other immigrants. And they said more people will migrate to these countries (Saudi Arabia, Qatar, Kuwait, etc.) since it is a lot easier to adapt to these countries due to their already living immigrant friends or relatives and a shared common notion of Islamic culture. Also, it would help these poor workers to earn good remittances in these countries.

b. Considers going to the Middle East, especially in Saudi Arabia, as an honor: $80 \%$ of the interviewee had stayed in Saudi Arabia during their immigrant life. Many of them first immigrated to countries like Kuwait, Iraq, Qatar, etc., and then moved into Saudi Arabia through legal or illegal means. Most of them agreed that the Islamic laws they saw their inaction may not be applicable in the Bangladeshi context, but they said that they feel lucky that they could visit the country of Prophet Muhammad (SM) and were happy to work there with Arab Muslims. The interviewees did not show any hostility or negative attitude towards the liberal attitude of Bangladesh regarding religion, still, they preferred the Islamic structure they saw in the Middle East.

c. Tendency to praise and prioritize Muslim authority and laws: The issue many of the interviewees acknowledges is how the Muslim authority and laws in Middle Eastern countries are humane and equal for everyone. Both legal and illegal workers agreed that the Muslim laws in the Middle Eastern countries see both Muslim and non-Muslim migrant workers in equal rights, if not allowing the non-Muslim workers more space to feel free to move and work. Now, it is interesting to mention their experience of punishment. Many of them were listed for lashing as a punishment due to their illegal status and they avoid this punishment through monetary settlement with local authority and police. This kind of settlement is government-approved. All most all of the interviewee considers this as a symbol of mercy provided to them by the government of the respected country they were in, some of the workers have faced uneasy situations regarding women-related issues. While many of them have seen that not everything appears to be the way they heard and expected, they tended to justify by saying that it all was internal issues of those societies and had nothing to do with 'Public' Islam. 
d. Religiousness and Nationality: Several interviewees reminiscent about their stay in Middle Eastern countries and talked about how they were treated by their employers. They said that the Bangladeshi migrant workers were more praised as they were more 'religious' and hard-working than the migrant workers from other Asian countries. When asked if they think that it was their Bangladeshi identity that helped them in achieving this reputation, the majority of them replied that actually, it was their religiousness that has earned the Bangladeshi workers the reputation of being good and reliable. In short, they believe that their Muslim identity along with their hard labor helped them establish a solid reputation among the employees.

e. Change of status due to monetary gain: As mentioned previously, many of the workers are from the same village and had to travel to the Middle East to improve their economic status. 11 of the interviewees have stated that they earned a good amount of money which helped them to change their economic and social status. According to them, they now donate in Local Mosques and Madrasah, hold a respectable position in many local meetings, and maintain a more 'Islamic' life than they previously did. Upon observing their homes and their contents, an abundance of Islamic books and materials were found. Then again, some of the interviewees who had not been fortunate enough to earn much, have stated that those who have become more solvent, now tend not to recognize many of their old friends and relatives who stayed with them in the Middle East and maintain an elaborated distanced relation with them. It is to be noted that most of these rich migrant workers are still working in the Middle East returning to the country only on vacation or events, and many of the poor ones had to return permanently whether they were legal or illegal. Also, it was found that the workers who work under any reputed organization tend to other the migrant day-to-day laborers who are working and have worked.

f. A tendency to hide bad experiences and unwillingness to comment on the problems in the Middle East: While the interviewees were willing to share their stories and experiences, they avoided commenting on the illegal visa procedure, the harassment they may have faced overseas and they refused to talk about any folly they saw in the Middle East both regarding Religiosity and Politics. Also, they were not willing to provide any information on the amount they had earned.

\section{Analysis from the findings}

\section{Economic and Socio-Cultural Identity}

Migrant workers mostly belong to poor and low classes in the power and class dynamics of Bangladeshi rural society prior to their migration. They experience an identity crisis as soon as they start earning more money than ever. They try to assimilate into the culture of the countries they migrate to and keep them in denial of their own 
culture. After returning to their homeland, many workers promote the Middle Eastern culture by wearing "jobba", "neqab" or fasting in Ramadan month one day ahead just like Arabs. This constructs a new identity for them. They separate themselves as purer Muslims because of their exposure to the land of pure and the others in their rurality as profanes since they do not have any exposure to the same land. The idea of Muslim cosmopolitanism is limited to the Middle Eastern countries and their norms and thus the migrant workers belong to a hierarchical Muslimhood than the others. Also, the idea of separation is brought by the monetary power which is a common factor to enhance power position in rural Bangladesh. Thus, a new identity is created for a migrant worker who earns at least 5 times better than a Bangladeshi worker.

\section{Psychological Affinity}

From the Freudian perspective, this paper offers a psychological view of the whole scenario of migrant workers after their return from the Middle East countries. Also, how collective conscience can affect psychologically has been discussed in this section. The collective conscience is a concept developed by Émile Durkheim (18581917). Durkheim sees the collective conscience as a key nonmaterial social fact (Durkheim xix). All social facts, material and nonmaterial, are best understood as external to and coercive of individual, psychological facts. While material social facts have a real, material existence, nonmaterial social facts exist within the ideas which can be navigated through psychoanalysis. The collective conscience is "the totality of beliefs and sentiments common to average citizens of the same society" (Ritzer 115). The whole situation of the migrant workers, thus, is directed by the collective consciousness of the rural place or societies of the country. According to Freud, there are three states of mind: conscious, subconscious, and unconscious which influence people's behavior (Freud 5). Collective consciousness, as in the shared beliefs of a particular group or society, leads an individual to possess ideas of a particular society or group that portray a certain culture or rituals. These rituals or cultures reside in the unconscious mind of individuals of those societies. People, subconsciously use those attitudes to maintain their lifestyles or behavior in conscious phenomena of their lives. For instance, the conscious idea of earning more, suppose in Saudi Arab, has been a common idea in the Muslim community of certain villages for a long time. Again, the myth of Arabs, being the land of pure Muslimhood resides in their very subconscious minds which control their will to explore the place. Thus, the workers who are exported are willing enough to go and do jobs there.

There is a transition in their psyche when they return. They mostly remain in denial of their slave status in Arab and conceal the fact. Workers mostly feign the higher status they always dreamed of and achieve it through the promotion of money and making properties. This is often an escapist attempt from their past identities as low class. As Freud opined that escapism is a necessary element of human lives to avoid the despair and crude reality in one's life (Freud 419), the workers escape their reality to find the peace of their minds and to live in their society with self-claimed dignity. 


\section{A Spatial Reading}

The Middle East has always been a land of Islamic myths and stories. Myths and stories are often created to explain the past, important events, and often these stories extend to the extent of explaining why people were created in the first place. Revolving around the gods, kings, and heroes of the time, they frequently addressed how the world was created, how mankind was created, why it rains, and so on. They played an important role in early education. Often these tales are connected to the geography or geology of an area. It is landscape, then, which results in some regions possessing a greater concentration of myth than others (Bates 1). In Bangladesh, people in the rural areas start their life with the entertainment form of the stories from the Arabian Nights. There are also the stories of different prophets who construct the ideals for rural people, based on which they try to build their lives and identities.

Rural people tend to believe in the ideas of prophets and their attitude towards these stories portrays their lifestyles based on them. French cultural theorist, sociologist, and philosopher Jean Baudrillard has noted, when authenticity is evoked, we are already in the world of the fake or fictional. Furthermore, because places are defined by the imagination of many, they occupy a realm that cannot be properly judged in terms of authenticity. In early twenty-first-century America, then, the appeal of "sense of place" may have more to say about being caught between traditionalism than about actual experience.

According to Wortham-Galvin, the place has truth based not just on the facts of its existence, but also on the things believed to be true about it(32). Making place is not just about physical creation and destruction; it is also about observation, narrative, association, and rituals associated with it. Inevitably, guided by various motives, people enact place for many reasons: to disseminate propaganda; to reveal the politics of context; to perpetuate tradition; to instill beliefs and values; to rebel against these patterns. Places whose outward form may thus appear permanent and universal are founded on the experiential, associational, and ephemeral nature of dwelling and being. (Wortham-Galvin et al. 33) Thus, the myths and stories tend to be a crucial part of the people of these rural areas to build their identities, faith and transform their ideas of nationalism and provoke them to turn into better Muslims.

The messiahs of Islam belong to the Middles Eastern countries and are considered pure. From a Foucauldian point of view, the Middle East can be considered as a utopia(Allen 520). Utopic ideas refer to the purity of Muslimhood in such places. Migrant workers tend to believe that they are purer when they visit such places. Often the truth is invisible to them that there is no such utopic place of Muslim purity. Here, place controls the desires of where the workers may want to be. Furthermore, the place is always in the making as Lefebvre would refer to it (412). Places like Arabia make Muslim people of rural areas be like them because they belong to the land of pure Muslims and they are rich enough to provide the workers with better wages than they get 
in the country. Had it not been Arab, the workers would have been less conjured up to go and be in a place like this. After several years of working, the sense of place affects their behavioral pattern. The place of the 'perceived' becomes the place of the 'lived'. Therefore, the workers tend to behave in a manner different than their own.

According to Dylan Trigg's concept of topophilia and topophobia, a place can create affection, fear, and disorder in people's minds (Trigg xxii). The affection towards the Middle Eastern countries largely depends on the ideas which people generated through stories. The affective bond between the rural people and the utopian place becomes stronger when they imagine that place to be their ultimate destination. Dylan Tuan argued that "place is security, space is freedom: we are attached to the one and long for the other" (Tuan 3). Hence, migrant workers' identity hybrid, and the multiple locations they inhabit are essential in conceiving and constructing who they are.

Through the myths and stories, the migrant workers become associated with the Middle Eastern countries like the Arab, and they become psychologically attached to the culture. Thus, the Middle East countries create a topophilia to migrant workers because they start belonging to a Muslim Cosmopolis. When these workers return to the country, by the virtue of their true Muslimhood due to their place identity and their imagined belongingness to another land enhances their power position in their countries as they assume. Again, the same places can create phobia initially when the workers start to lose their own identity and become mere Bangladeshi migrant workers, belonging to the lower-class dynamics in Arab. This demystifies their sense of identity and belongingness because, in Arabs, they're mere workers, not ones of their own. This phobia awakens an aversion towards the same place which they learned to love from the beginning. Thus, a place can construct identity and play a role of affection and fear when the identity is in concern.

Cosmopolitanism itself is a spatial concern. Cosmopolitanism, as Bassnett argued is a provincial attitude (Bassnett 63). It is learned rather than experienced. Thus, the rural migrant workers tend to view the world through the eyes of the Middle East. In Middle East countries, the workers learn to behave in the manners their employers would want them to even if it is often contradictory to the culture and manners of their homeland. More importantly, they bring into their land to prove them as different and superior beings. Muslim cosmopolitanism, in this case, is a learned behavior because of their exposure to Middle Eastern countries.

\section{Awareness of cultural assimilation}

The migrant workers of rural Bangladesh have dual identities- the Bangladeshi Muslim migrant workers and the Muslim migrant workers. Mostly if the workers are asked to choose between the two, they will go for the latter. Being a Muslim is greater than being a Bangladeshi Muslim. The sense of nation is non-existent for them. They are hardly aware of nationhood. They are concerned about their status as pure Muslims. In such a case, the workers express their obligation towards the Middle East more than their own country. Their sense of brotherhood is confined among the Muslim umma rather 
than the whole nation of mixed religious beliefs.

Cultural assimilation takes place when the migrants change their original place. But are they aware of their assimilation? This is an in-between phenomenon since assimilation takes place subconsciously. They do not have enough sense to contain a separate cultural and political identity except for Muslim identity since their Muslimhood helps them earn better than their national identity. Also, the sense of nationalism cannot be a bigger issue for them because of their lack of education in the mainstream educational system which provides the idea of national culture. This lack leads them to grasp the only things they know and they tend to highlight those superficially. Again, they earn a huge amount of remittance which enhances the economy and it evokes a sense of superiority among them. Therefore, they do not mind claiming themselves as belonging to the place they work in. It separates them from the rest of the people from their own country and makes them unique and different. Even though the cultural assimilation may take hold of their sense of identity subconsciously, this is a boundary they create consciously and are aware of creating an inferior 'other' in comparison to their superior place in society. This transition in their own identity takes place without any notice since their concept of nationhood is relatively vague and, in some cases, nonexistent. For instance, the migrant workers often identify the concept of the country with The Middle East more than they identify with their actual homeland. The assimilation and its application in their behavior, therefore, remain a subconscious process in dealing with their identities and other things.

\section{The Diasporic Shift and Negotiation}

Bangladeshi migrant workers who are Muslims often hold the idea of the hybrid Muslimhood of Bangladesh. They tend to have a pure Muslimhood which can be found in the Middle East countries and therefore, tend to migrate there as workers. This diasporic shift is not only a process to create an inferior other than themselves but also a step to create a status for them where they come from. The status is created by the currency they earn in those countries and through which they build houses, buy lands or marry more than once. The shift in the rural scenario thus happens through monetary gain.

However, the negotiation between their past identity as low-class Muslims in a rural area and their new identity as migrant Muslim workers hangs in the balance. They prefer the later identity which makes them respected in their own rurality. When in the Middle East, they tend to behave like one of their people because it makes them purer Muslim and in their own country, they behave the same because it gives them the upper position in power dynamics. There is no place for their national identity because it neither provides them with the purity of Muslim Cosmopolis nor gives the hierarchical position. The negotiation thus offers no place for the national identity rather it addresses the Muslim identity on a scale of purity. 


\section{Conclusion}

This article addressed the troublesome identity construction that the Bangladeshi migrant workers experience due to their monetary gain in Middle Eastern countries. They are often not aware of their cultural assimilation as it happens due to their collective consciousness since most of the rural areas in Bangladesh harbors the idea of "pure" Muslimhood from time immemorial. Consequently, they inherit an idealized onceptualization of the Middle East and pass it from one generation to another based on a believed religious obligation. This identity, further, helps them to construct their status as superior since it is, according to them, a form of purity and completeness. The income they receive is more than that of the non-migrants, assisting them to be financially superior. The Middle East and South East Muslim communities in Asia have creatively employed and adapted cosmopolitan ideals and pluralist tendencies to produce necessary contexts for mutual tolerance, effective communication, and exchange of respect between and within Muslim groups in the Islamic states. However, the irony is that the establishment of Muslim Cosmopolitanism has created hegemonic pockets of the 'other'. In this paper, the focus was on the Muslim communities in rural Bangladesh where the bread earners of many families are migrant workers, working in several Middle Eastern Muslim countries. These Bangladeshi migrant workers in rural areas subconsciously attempt to change their identity from being Bangladeshi to being a transnational Muslim with an Arab affinity. The shift of identity produces more 'pure' Muslims, and thus it creates a hierarchy. Since these migrant workers spend a long time in these Middle Eastern countries for their work, they eventually start to believe that they belong to this 'bigger' and 'better' Global Muslim Community. This results in creating a hierarchical position in their rural community among themselves and the 'Other' Non-migrant Bangladeshi Muslims, and thus constructing a power dynamic in rural Muslim communities in Bangladesh.

\section{Works Cited}

Allen, Amy. "Emancipation without utopia: Subjection, modernity, and the normative claims of feminist critical theory." Hypatia vol.30, no.3, 2015, pp.513-529. https://doi.org/10.1111/hypa.12160

Allport, Gordon W., and J. Michael Ross. "Personal religious orientation and prejudice." Journal of personality and social psychology vol.5, issue.4, 1967, pp. 432. https://doi.org/10.1037/h0021212

Appiah, A., \& Gülfidan, F. Cosmopolitanism: Ethics in a World of Strangers. Penguin Publications, 2007, p. xv.

Appleton, Michael. "The political attitudes of Muslims studying at British universities in the post-9/11 world (Part I)." Journal of Muslim Minority Affairs, vol.25, no.2, 2005, pp 171-191. https://doi.org/10.1080/13602000500350488

Aziz, Muhammad Faisal Abdul. "Cosmopolitan Islam and the Forging of Bangsa Malaysia." The 
Md. Nizam Ul Hossain \& Nodi Islam, Muslim Cosmopolitanism in Rural Bangladesh: The Construction of Power Dynamics vis-à-vis Cosmopolitan Identity

Star, Muslim Youth Movement Malaysia (ABIM), 8 Jan. 2021, www.thestar.com.my/opinion/letters/2021/01/08/cosmopolitan-islam-and-the-forging-ofbangsa-malaysia

Azra, Azyumardi. The Origins of Islamic Reformism in Southeast Asia: Networks of MalayIndonesian and Middle Eastern'Ulam?'in the Seventeenth and Eighteenth Centuries. University of Hawaii Press, 2004.

Banks, James A. Democracy and Diversity: Principles and Concepts for Educating Citizens in a Global World. Center for Multicultural Education, 2003.

Bates, Kath. "Geo-Mythology." Geo-Mythology I Oxford Open Learning, The Oxford Open Learning Trust, 5 Oct. 2018, https://www.ool.co.uk/blog/geo-mythology/

Batson, C. D. Sociobiology and the role of religion in promoting prosocial behavior. Journal of Personality and Social Psychology, vo.4, no3, 1983, p.p.323-48, http://www.jstor.org/stable/3590600.

Batson, C. D., \& Schoenrade, P. "Measuring religion as quest". Journal for the Scientific Study of Religion, vol. 30,no.4, 1991, p. 430-447. https://www.jstor.org/stable/1387277

Baudrillard, Jean. Simulacra and Simulation. Semiotext(e), 1981.

Bassnett, Susan. Comparative Literature: A Critical Introduction. Blackwell, 1998, p.63.

Berry, J. W., Poortinga, Y. H., Segall, M. H., \& Dasen, P. R. Cross-cultural psychology: Research and applications (2nd ed.). Cambridge University Press, 2002.

Beck, Ulrich. What is Globalization? Polity Press, 1997.

Bhabha Homi K. Unsatisfied: Notes on Vernacular Cosmopolitanism. Garcia-Moreno Laura, Pfeiffer Peter C., editors. Text and Nation: Cross-Disciplinary Essays on Cultural and National Identities. Camden House, 1996. p. 191-207.

Burris, Christopher T., et al. "“For God and Country." Journal of Cross-Cultural Psychology, vol. 31, no. 4, 2000, p. 517-527. https://doi.org/10.1177/0022022100031004005

Case, L., Willing, I., Skrbis, Z. Unrecognized cosmopolitans: mobility and openness among globally engaged family farmers. Mobilities, vol. 9, no.1, 2014, p. 84-103. https://doi.org/10.1080/17450101.2013.796784

Castles, Stephen and Miller, Mark. The Age of Migrations: International Population Movement in the Modern World. 3rd ed. MacMillan Publishers, 2003.

Clifford, James. "Mixed Feelings". Cosmopolitics: Thinking and Feeling Beyond the Nation. University of Minnesota Press, 1998, p. 362-370.

Cohen, R., \& Vertovec, S. Conceiving cosmopolitanism: Theory, context, and practice. Oxford University Press, 2011, p.5-14.

Derrida, Jacques. "Hospitality”. Angelaki. 5: 3, 2000, p. 3 - 18.

Durkheim, Emile. The Division of Labour in Society. Free Press, 1997, p. xix.

Ebaugh, H. R. Religion and the new immigrants. In M. Dillon (Ed.), Handbook of the sociology of religion. Cambridge University Press, 2003, p. 225-239.

Etzold, B., \& Mallick, B. International Migration from Bangladesh - Country Profile Bangladesh-Migration. 2015.

Freedman, Jonathan. “'The Ethics of Identity': A Rooted Cosmopolitan.” The New York Times, 12 June 2005, www.nytimes.com/2005/06/12/books/review/the-ethics-of-identity-arooted-cosmopolitan.html

Freud, Sigmund. The Ego and the Id. General Press, 2020, p. 5-10. Introductory lectures on Psychoanalysis, The Penguin Freud Library, Vol, 1, 1991, p. 419. 
Jenkins, Henry. Convergence Culture. New York University Press, 2006.

Gidwani, Vinay, and Kalyanakrishnan Sivaramakrishnan. "Circular migration and rural cosmopolitanism in India." Contributions to Indian Sociology, vol.37, no. 2 (2003, pp.339-367. https://doi.org/10.1177/006996670303700114

Giubilaro, Donatella. Migration from the Maghreb and Migration Pressures: Current Situation and Future Prospects. Geneva: International Labor Office, 1997.

Hoge, Dean. A validated intrinsic religious motivation scale. Journal for the Scientific Study of Religion,vol. 11, no.4, 1972, pp. 369-376. https://www.jstor.org/stable/1384677

Ebstyne King, Pamela. "Religion and identity: The role of ideological, social, and spiritual contexts." Applied Developmental Science, vol., no.3 2003, pp.197-204. https://doi.org/10.1207/S1532480XADS0703 11

Kapiszewski, Andrzej. "Arab versus Asian migrant workers in the GCC countries." South Asian migration to gulf countries. Routledge India, 2017. 66-90.

Khairudin, Aljunied Syed Muhd. Muslim Cosmopolitanism: Southeast Asian Islam in Comparative Perspective. Edinburgh University Press, 2017, p. 49-52.

Lefebvre, Henri. The Production of Space. Blackwell, 1991, P. 412.

Leichtman, Mara A, and Dorothea Schulz. "Introduction to Special Issue: Muslim Cosmopolitanism: Movement, Identity, and Contemporary Reconfigurations." City \& society vol. 24, no.1, 2012,p. 1-6. https://doi.org/10.1111/j.1548-744X.2012. 01064.x

Matiaske, Wenzel. "Cosmopolitanism: Ethics in a World of Strangers." Management Revue, vol.19, .4, 2008, 340 .

Nielsen, Greg M. "Answerability with Cosmopolitan Intent: An ethics-based politics for acts of urban citizenship", in Acts of Citizenship, Isin, Engin F. and Nielsen, Greg M. (eds). Zed Books, 2008.

Nussbaum, Martha. "Patriotism and cosmopolitanism." The cosmopolitan Reader,1994, p. 155162.

Petrus, Joseph A. "Marx and Engels on the National Question." The Journal of Politics, vol.33, no.3, 1971, pp. 797-824. http://www.jstor.org/stable/2128282

Pancer, S. Mark, et al. "Cognitive Complexity of Expectations and Adjustment to University in the First Year." Journal of Adolescent Research, vol. 15, no. 1, 2000, p. 38-57., https://doi.org/10.1177/0743558400151003

Samers, Micael E. "Diaspora Unbound: Muslim identity and the erratic regulation of Islam in France". International Journal of Population Geography. Vol.9,no.4, 2003, p. 351-364. https://doi.org/10.1002/ijpg.292

Song, Geng, and Tracy K. Lee. "“New man" and "new lad" with Chinese characteristics? Cosmopolitanism, cultural hybridity and men's lifestyle magazines in China." Asian Studies Review 36.3, 2012, pp. 345-367. https://doi.org/10.1080/10357823.2012.711808

Trigg, Dylan. Topophobia: A Phenomenology of Anxiety. Bloomsbury, 2017, p. xxi-xxii.

Tuan, Yi-fu. Space and Place: The Perspective of Experience, University of Minnesota Press, 2018.

Werbner, Pnina. "Vernacular Cosmopolitanism." Theory, Culture \&amp; Society, vol. 23, no. 23, 2006, pp. 496-498., https://doi.org/10.1177/026327640602300291

Woods, Michael. "Engaging the Global Countryside: Globalization, Hybridity and the Reconstitution of Rural Place." Progress in Human Geography, vol. 31, no. 4, 2007, p. 485-507., https://doi.org/10.1177/0309132507079503

Wortham-Galvin, B. D., et al. "Mythologies of Placemaking." Re-Placing. Places Journal. vol. 20, 1, 1 June 2008, p. 32-40. https://escholarship.org/uc/item/6bp6c7xf 
Md. Nizam Ul Hossain \& Nodi Islam, Muslim Cosmopolitanism in Rural Bangladesh: The Construction of Power Dynamics vis-à-vis Cosmopolitan Identity

\section{The Authors}

\section{Md. Nizam Ul Hossain}

Department of English, Southeast University, Banani, Dhaka, Bangladesh Email: nizamulhossain171@gmail.com

\section{Nodi Islam}

Department of English, Southeast University, Banani, Dhaka, Bangladesh Email: nodiislam150@gmail.com

\section{The Article}

Date Sent: $25 / 11 / 2021$

Date Revised: 22/01/2022

Date Accepted: 02/02/2022 